\title{
FUZZY MODEL FOR PREDICTING CLOACAL TEMPERATURE OF BROILER CHICKENS UNDER THERMAL STRESS
}

\section{Lucas H. P. Abreu ${ }^{*}$, Tadayuki Yanagi Junior', Alessandro T. Campos², Dian Lourençoni ${ }^{3}$, Marcelo Bahuti²}

\author{
${ }^{1 *}$ Corresponding author: Federal University of Lavras/ Lavras - MG, Brazil. E-mail: lucas.abreu@deg.ufla.br \\ ORCID ID: https://orcid.org/0000-0002-5295-0177
}

\section{KEYWORDS}

physiological response, thermal environment, mathematical modeling, fuzzy logic.

\begin{abstract}
Broiler chickens submitted to different intensities and durations of thermal stress are subject to variation in cloacal temperature and, consequently, to a decrease in performance. Given the complexity of these interactions, artificial intelligence is a useful methodology for decision-making. Thus, this study aimed to assess and predict, by means of a fuzzy model, the cloacal temperature of broiler chickens submitted to thermal stress in the second week of life, with varying durations and intensities, in climatized wind tunnels. Mamdani's inference and defuzzification methods by means of the center of gravity were used. One hundred and twenty rules were elaborated. The developed fuzzy model was used to predict the cloacal temperature of broiler chickens on the day of thermal stress as a function of air dry-bulb temperature $\left({ }^{\circ} \mathrm{C}\right)$, stress duration (days), and the number of days after thermal stress. Cloacal temperature values simulated by the fuzzy model showed standard deviations and percentage errors lower than 0.02 and $0.08 \%$, respectively, when compared to those obtained experimentally.
\end{abstract}

\section{INTRODUCTION}

Broiler chicken production in Brazil and the search for higher productivity and quality of the supplied product have grown in the last decades, increasing the competitiveness of this sector in face of the new demands of the consumer market.

The increased demand for chicken meat has led to more and more improvements in productivity. Thus, rearing of genetically improved birds, balanced nutrition, and an environment adapted to bird characteristics should be associated. In this context, broiler chicken rearing in a suitable environment is essential in modern poultry farming since it aims to achieve high productivity in a relatively small space and time.

Because broiler chickens are homeothermic, they are able to maintain their body temperature in a relatively narrow range by means of physiological and behavioral mechanisms. However, the thermoregulatory system of these birds is not fully developed in the first weeks of life (Furlan, 2006) and if submitted to thermal stress conditions, their welfare may be affected and, consequently, their performance.
Thus, when environmental conditions are not within the range considered as suitable, which is characterized by the thermoneutral zone, the environment becomes uncomfortable. An important parameter to determine the comfort condition of birds is the cloacal temperature (Ferreira et al., 2012). The variation of cloacal temperature is a physiological response to the air temperature and relative humidity conditions resulting from the storage or dissipation of metabolic heat (Silva et al., 2003). Broiler chickens submitted to different intensities and durations of thermal stress are subject to cloacal temperature variation aiming to increase or decrease heat dissipation.

Therefore, the prediction of cloacal temperature can be used to assist the decision-making of commercial farms for the activation of climatized systems. This prediction favors the use of one of the main physiological responses related to the assessment of thermal stress (Silva \& Vieira, 2010; Costa et al., 2012) in an indirect and non-invasive way.

Among the several applied methodologies, the modeling of fuzzy sets consists of techniques that allow strict handling of qualitative information since they use the transformation of numerical values into linguistic variables determined by membership functions (Pandorfi et al., 2012; Campos et al., 2013; Schiassi et al., 2015).

${ }^{2}$ Federal University of Lavras/ Lavras - MG, Brazil

${ }^{3}$ Federal University of Vale do São Francisco/ Juazeiro - BA, Brazil

Received in: 10-23-2017

Accepted in: 12-7-2018 
Thus, the estimation of cloacal temperature as a function of thermal environment constitutes a problem in which the application of fuzzy logic can be applied. In this context, this study aimed to develop a fuzzy mathematical model to predict the cloacal temperature of broiler chickens submitted to different intensities and durations of thermal stress in their second week of life.

\section{MATERIAL AND METHODS}

An experiment with broiler chickens submitted to different intensities and duration of thermal stress during their second week of life was carried out to perform the modeling. The data obtained in the experiment were used to develop a model capable of predicting the cloacal temperature of birds.

Data collection was performed in four climatized wind tunnels installed in a laboratory equipped with two air conditioning systems with a power of $5.275 \mathrm{~kW}(18,000$ BTU) each and used to maintain the air temperature inside the experimental room. Each climatized tunnel had a cage with dimensions of $0.40 \times 0.60 \mathrm{~m}$ with three divisions of identical dimensions and areas of $0.08 \mathrm{~m}^{2}$ each.

A total of 240 male and female Cobb 500 strain broiler chickens, aged between one and 21 days were used in the experiment. These birds were obtained with 1 day of life from the same commercial hatchery. Sixty birds were used at each stage, 15 of them at each wind tunnel, divided into 5 birds for each division, with independent feeding and drinking troughs.

A bird from each division was removed weekly and taken to a production environment. Thus, only three birds remained at each division in the third week of life, maintaining the recommended rearing density.
During the experimental period, the birds were fed a balanced diet, based on corn and soybean meal, following the nutritional recommendations of Rostagno et al. (2011). Feed and water were available ad libitum. Cleaning of wind tunnels and cages was carried out daily to reduce gas formation, thus providing an adequate environment for broiler chicken performance.

The cloacal temperature was measured daily using a TP-100 Instrutherm ${ }^{\circledR}$ thermometer with a scale ranging from -50 to $450{ }^{\circ} \mathrm{C}$ and accuracy of $\pm 0.15^{\circ} \mathrm{C}$. Before each use, the thermometer was sterilized and introduced into the bird cloaca until a stable value was obtained.

The experiment was performed in four stages, with 13 treatments and 3 replications for each treatment. During the first and third week of life of birds, the air dry-bulb temperatures were maintained in the thermoneutral zone for birds, whose values are 33 and $27^{\circ} \mathrm{C}$, respectively (Abreu et al., 2000; Schiassi et al., 2015). At each stage, four air temperatures were assessed in the second week of life of birds $\left(33,30,27\right.$, and $\left.24^{\circ} \mathrm{C}\right)$ from the eighth day of life. The temperature levels were selected considering the optimum temperature ranges recommended in the literature for the second week of life of birds (Curtis, 1983; Abreu et al., 2000), whose upper and lower limits were extrapolated to generate discomfort due to low $\left(27\right.$ and $\left.24{ }^{\circ} \mathrm{C}\right)$ and high temperatures $\left(33^{\circ} \mathrm{C}\right)$.

Four levels of thermal stress duration were assessed: $1,2,3$, and 4 days. Soon thereafter, the air temperatures returned to the conditions considered of comfort. During all tests, air relative humidity was maintained at $60 \pm 1 \%$ and airspeed at $0.2 \pm 0.1 \mathrm{~m} \mathrm{~s}^{-1}$, characterized as of comfort for animals (Medeiros et al., 2005). The intensity of luminosity was also controlled according to the Cobb-Vantress (2008) manual. For the first, second, and third week, luminosity values were set at 25, 10, and 5 lux, respectively. Table 1 shows the assessed treatments.

TABLE 1. Air dry-bulb temperature and stress maintenance days applied to broiler chickens from one to 21 days of age maintained in climatized wind tunnels.

\begin{tabular}{|c|c|c|c|c|c|c|c|c|c|c|}
\hline \multirow{2}{*}{ Stg } & \multirow{2}{*}{ Tunnel } & \multicolumn{9}{|c|}{ Days of life } \\
\hline & & 1 to 7 & 8 & 9 & 10 & 11 & 12 & 13 & 14 & 15 to 21 \\
\hline \multirow{4}{*}{1} & A & \multirow{4}{*}{$33^{\circ} \mathrm{C}$} & $33^{\circ} \mathrm{C}$ & $30^{\circ} \mathrm{C}$ & $30^{\circ} \mathrm{C}$ & $30^{\circ} \mathrm{C}$ & $30^{\circ} \mathrm{C}$ & $30^{\circ} \mathrm{C}$ & $30^{\circ} \mathrm{C}$ & \multirow{4}{*}{$27^{\circ} \mathrm{C}$} \\
\hline & $\mathrm{B}$ & & $33^{\circ} \mathrm{C}$ & $33^{\circ} \mathrm{C}$ & $30^{\circ} \mathrm{C}$ & $30^{\circ} \mathrm{C}$ & $30^{\circ} \mathrm{C}$ & $30^{\circ} \mathrm{C}$ & $30^{\circ} \mathrm{C}$ & \\
\hline & $\mathrm{C}$ & & $33^{\circ} \mathrm{C}$ & $33^{\circ} \mathrm{C}$ & $33^{\circ} \mathrm{C}$ & $30^{\circ} \mathrm{C}$ & $30^{\circ} \mathrm{C}$ & $30^{\circ} \mathrm{C}$ & $30^{\circ} \mathrm{C}$ & \\
\hline & $\mathrm{D}$ & & $33^{\circ} \mathrm{C}$ & $33^{\circ} \mathrm{C}$ & $33^{\circ} \mathrm{C}$ & $33^{\circ} \mathrm{C}$ & $30^{\circ} \mathrm{C}$ & $30^{\circ} \mathrm{C}$ & $30^{\circ} \mathrm{C}$ & \\
\hline \multirow{4}{*}{2} & $\mathrm{~A}$ & \multirow{4}{*}{$33^{\circ} \mathrm{C}$} & $27^{\circ} \mathrm{C}$ & $30^{\circ} \mathrm{C}$ & $30^{\circ} \mathrm{C}$ & $30^{\circ} \mathrm{C}$ & $30^{\circ} \mathrm{C}$ & $30^{\circ} \mathrm{C}$ & $30^{\circ} \mathrm{C}$ & \multirow{4}{*}{$27^{\circ} \mathrm{C}$} \\
\hline & $\mathrm{B}$ & & $27^{\circ} \mathrm{C}$ & $27^{\circ} \mathrm{C}$ & $30^{\circ} \mathrm{C}$ & $30^{\circ} \mathrm{C}$ & $30^{\circ} \mathrm{C}$ & $30^{\circ} \mathrm{C}$ & $30^{\circ} \mathrm{C}$ & \\
\hline & $\mathrm{C}$ & & $27^{\circ} \mathrm{C}$ & $27^{\circ} \mathrm{C}$ & $27^{\circ} \mathrm{C}$ & $30^{\circ} \mathrm{C}$ & $30^{\circ} \mathrm{C}$ & $30^{\circ} \mathrm{C}$ & $30^{\circ} \mathrm{C}$ & \\
\hline & $\mathrm{D}$ & & $27^{\circ} \mathrm{C}$ & $27^{\circ} \mathrm{C}$ & $27^{\circ} \mathrm{C}$ & $27^{\circ} \mathrm{C}$ & $30^{\circ} \mathrm{C}$ & $30^{\circ} \mathrm{C}$ & $30^{\circ} \mathrm{C}$ & \\
\hline \multirow{4}{*}{3} & A & \multirow{4}{*}{$33^{\circ} \mathrm{C}$} & $24^{\circ} \mathrm{C}$ & $30^{\circ} \mathrm{C}$ & $30^{\circ} \mathrm{C}$ & $30^{\circ} \mathrm{C}$ & $30^{\circ} \mathrm{C}$ & $30^{\circ} \mathrm{C}$ & $30^{\circ} \mathrm{C}$ & \multirow{4}{*}{$27^{\circ} \mathrm{C}$} \\
\hline & $\mathrm{B}$ & & $24^{\circ} \mathrm{C}$ & $24^{\circ} \mathrm{C}$ & $30^{\circ} \mathrm{C}$ & $30^{\circ} \mathrm{C}$ & $30^{\circ} \mathrm{C}$ & $30^{\circ} \mathrm{C}$ & $30^{\circ} \mathrm{C}$ & \\
\hline & $\mathrm{C}$ & & $24^{\circ} \mathrm{C}$ & $24^{\circ} \mathrm{C}$ & $24^{\circ} \mathrm{C}$ & $30^{\circ} \mathrm{C}$ & $30^{\circ} \mathrm{C}$ & $30^{\circ} \mathrm{C}$ & $30^{\circ} \mathrm{C}$ & \\
\hline & $\mathrm{D}$ & & $24^{\circ} \mathrm{C}$ & $24^{\circ} \mathrm{C}$ & $24^{\circ} \mathrm{C}$ & $24^{\circ} \mathrm{C}$ & $30^{\circ} \mathrm{C}$ & $30^{\circ} \mathrm{C}$ & $30^{\circ} \mathrm{C}$ & \\
\hline 4 & $\mathrm{~A}, \mathrm{~B}, \mathrm{C}$ and $\mathrm{D}$ & $33^{\circ} \mathrm{C}$ & & & & $30^{\circ} \mathrm{C}$ & & & & $27^{\circ} \mathrm{C}$ \\
\hline
\end{tabular}

Stg $=$ Stage. 
Fuzzy sets were designed in order to characterize each variable and a membership functions was determined for each set. To quantify the importance of temperature variation in the second week of life, thermal stress duration (days), air dry-bulb temperature $\left({ }^{\circ} \mathrm{C}\right)$, and days after thermal

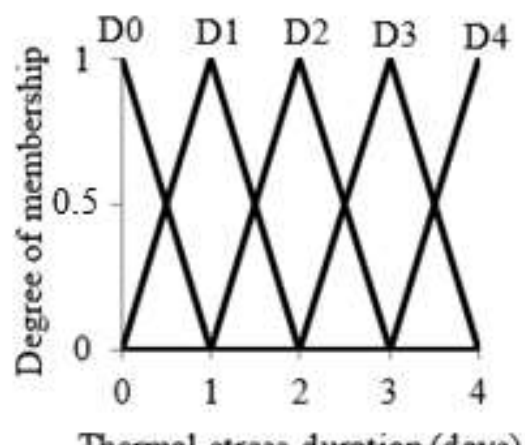

Thermal stress duration (days) stress (days) were assigned as input variables. Thus, intervals for each input variable were determined according to triangular membership function (Figure 1), which best represent the input data, as used by several authors (Ganga et al., 2011; Ponciano et al., 2012; Campos et al., 2013).

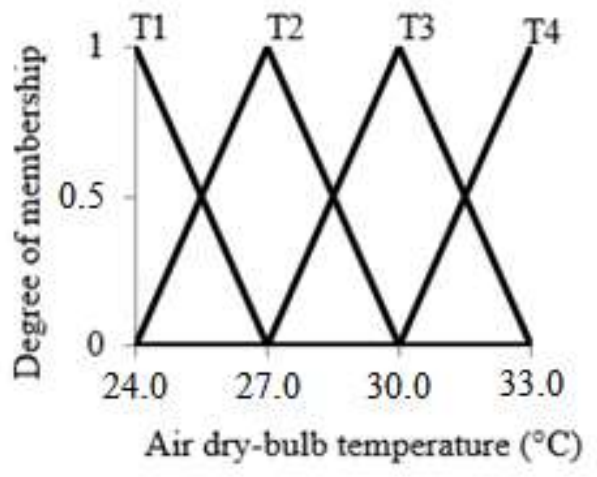

(b)

(a)

DA0 DA1 DA2 DA3 DA4 DA5

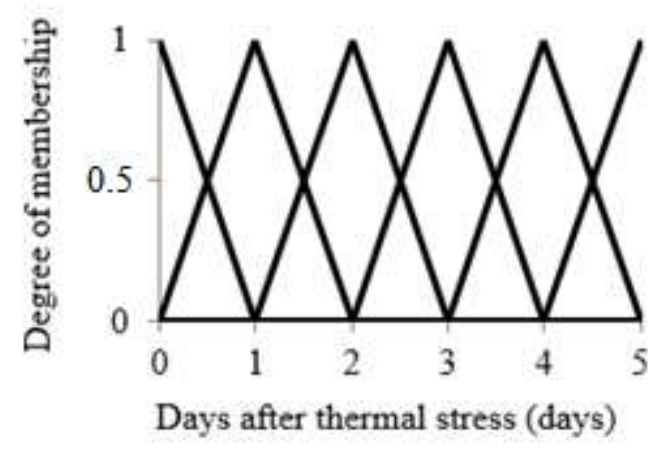

(c)

FIGURE 1. Membership functions for the input variables: a) thermal stress duration (days), b) air dry-bulb temperature $\left({ }^{\circ} \mathrm{C}\right)$, and c) days after thermal stress (days).

Cloacal temperature $\left({ }^{\circ} \mathrm{C}\right)$ was defined as the model output variable. This variable was analyzed during the days of thermal stress in the second week up to five days after the established thermal stress period.

For the output variable, after the preliminary adjustment test, the membership functions were characterized as triangular (Figure 2) because they reproduce better responses with lower standard deviation values, which is in accordance with that observed by several authors (Castro et al., 2012; Ponciano et al., 2012).
The Mamdani's inference method was applied to perform all the fuzzy reasoning. This method provides the answers of a set, according to the combinations of input values with their relative degrees of membership by means of a minimum operator and then by defining rules through a maximum operator. The center of gravity (centroid or center of area) method was used in the defuzzification, which admits all the alternatives of outputs, converting the sets into numeric values (Castro et al., 2012). 


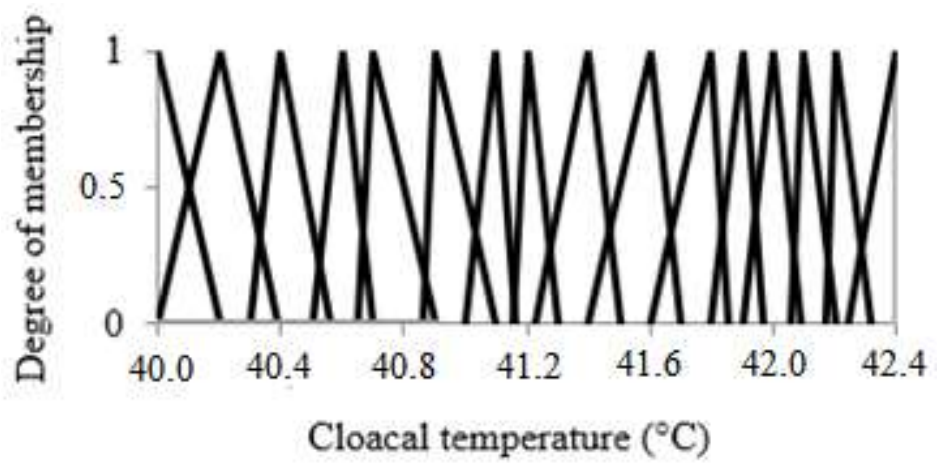

FIGURE 2. Membership functions for the output variable cloacal temperature $\left({ }^{\circ} \mathrm{C}\right)$.

The rules were defined by means of linguistic sentences based on the data collected in the first stage of this experiment and with the assistance of three specialists. According to Silva \& Costa (2004), a specialist is a professional who has deep and specific knowledge in a given area. Thus, for the development of the fuzzy logic, it is necessary that the professional be qualified to avoid the possibility of contradictions in the interactions between the rules (Cherri et al., 2011). For selecting the specialist, the methodology was used as in Yanagi Júnior et al. (2012). Therefore, three specialists with experience in the area of animal ambience and fuzzy modeling for more than ten years helped to set up the rules.

According to the combinations of thermal stress duration, air dry-bulb temperature, and days after thermal stress, 120 rules were defined and, for each rule, a weighting factor equal to 1 was assigned, as adopted by several authors (Ponciano et al., 2012; Yanagi Junior et al., 2012; Schiassi et al., 2013).

The validation of the developed fuzzy model was performed by means of the cloacal temperature data obtained experimentally. Cobb strain broiler chickens were submitted to different intensities and duration of stress during the second week of life and their performance analyzed during 21 days.

\section{RESULTS AND DISCUSSION}

Birds submitted to conditions of thermal discomfort in the first weeks of life may have their welfare affected, negatively affecting their productive performance. In addition, thermal conditions under which birds undergo in the first weeks of life are relevant to animal development in the future (Marchini et al., 2009).

Abreu et al. (2012) studied morphological measures as a function of weight and age of birds by means of images and verified that broiler chickens submitted to high cyclic ambient temperature presented an increase in cloacal temperature. This effect is clearly observed in the experimental data, in which the birds submitted to thermal stress ( 0 days) (Table 2 ) at a temperature of $33^{\circ} \mathrm{C}$, varying only the thermal stress duration during the second week of life, showed values of cloacal temperature with duration of one $\left(\mathrm{CT}^{1}\right)$, two $\left(\mathrm{CT}^{2}\right)$, three $\left(\mathrm{CT}^{3}\right)$, and four days $\left(\mathrm{CT}^{4}\right)$ of 41.2, 41.6, 41.9 , and $41.9^{\circ} \mathrm{C}$, respectively.

In the control treatment, in which the birds were submitted to air dry-bulb temperature of $30^{\circ} \mathrm{C}$ during the second week, the average value of cloacal temperature was $41.8{ }^{\circ} \mathrm{C}$, confirming the range between 41.2 and $42.2^{\circ} \mathrm{C}$ considered as of comfort for broiler chickens, as cited by Tao \& Xin (2003). Nazareno et al. (2009) found the same range of cloacal temperature values for birds reared in picket and confined systems. Thus, the air dry-bulb temperature of $30{ }^{\circ} \mathrm{C}$ can be confirmed as the comfort temperature for broiler chickens in the second week of life, which is in accordance with the results obtained by other authors (Medeiros et al., 2005).

Cloacal temperature values simulated by the fuzzy model as a function of the thermal stress temperature, thermal stress duration, and days after thermal stress in the second week of life were compared to the experimental data obtained in climatized wind tunnels (Table 2). Average standard deviations of $0.01,0.01,0.02$, and $0.01{ }^{\circ} \mathrm{C}$ and the corresponding percentage errors of $0.05,0.04,0.08$, and $0.04 \%$ were calculated for $\mathrm{CT}^{1}, \mathrm{CT}^{2}, \mathrm{CT}^{3}$, and $\mathrm{CT}^{4}$, respectively.

In the study carried out by Ponciano et al. (2012) to predict the productive performance of broiler chickens from one to 21 days of age using fuzzy mathematical modeling, the authors obtained average values of standard deviations for feed intake (FI), weight gain (WG), and feed conversion (FC) of $4.31 \mathrm{~g}, 4.76 \mathrm{~g}$, and $0.02 \mathrm{~g} \mathrm{~g}^{-1}$, respectively, and percentage errors of $2.38,2.94$, and $2.16 \%$, respectively, thus demonstrating the efficiency of the proposed fuzzy model in simulating parameters involving poultry production.

Linear regressions of values obtained experimentally and simulated by the fuzzy model are shown in Figure 3, in which the coefficients of determination $\left(\mathrm{R}^{2}\right)$ were 0.998 , 0.992, 0.977, and 0.981 for $\mathrm{CT}^{1}, \mathrm{CT}^{2}, \mathrm{CT}^{3}$, and $\mathrm{CT}^{4}$, respectively. To assess the performance of adult broiler chickens as a function of temperature, relative humidity, and airspeed, Medeiros et al. (2005) developed a mathematical model to predict FI, WG, and FC and found values of coefficients of determination of $0.91,0.89$, and 0.72 , respectively. 
TABLE 2. Comparison of cloacal temperature $\left({ }^{\circ} \mathrm{C}\right)$ with stress duration of one $\left(\mathrm{CT}^{1}\right)$, two $\left(\mathrm{CT}^{2}\right)$, three $\left(\mathrm{CT}^{3}\right)$, and four days $\left(\mathrm{CT}^{4}\right)$ for broiler chickens from one to 21 days of age obtained experimentally and simulated by the model.

\begin{tabular}{|c|c|c|c|c|c|c|c|c|c|c|c|c|c|c|c|c|c|}
\hline \multirow{2}{*}{$\begin{array}{c}\text { Thermal } \\
\text { stress } \\
\text { temperature } \\
\left({ }^{\circ} \mathbf{C}\right)\end{array}$} & \multirow{2}{*}{$\begin{array}{l}\text { Days } \\
\text { after } \\
\text { stress }\end{array}$} & \multicolumn{4}{|c|}{ Experimental data } & \multicolumn{4}{|c|}{ Fuzzy simulation } & \multicolumn{4}{|c|}{ Standard deviation } & \multicolumn{4}{|c|}{ Error (\%) } \\
\hline & & $\mathbf{C T}^{1}$ & $\mathbf{C T}^{2}$ & $\mathrm{CT}^{3}$ & $\mathrm{CT}^{4}$ & $\mathrm{CT}^{1}$ & $\mathrm{CT}^{2}$ & $\mathrm{CT}^{3}$ & $\mathrm{CT}^{4}$ & $\mathrm{CT}^{1}$ & $\mathrm{CT}^{2}$ & $\mathrm{CT}^{3}$ & $\mathrm{CT}^{4}$ & $\mathrm{CT}^{1}$ & $\mathrm{CT}^{2}$ & $\mathrm{CT}^{3}$ & $\mathrm{CT}^{4}$ \\
\hline \multirow{6}{*}{33} & $\mathbf{0}$ & 41.2 & 41.6 & 41.9 & 41.9 & 41.2 & 41.6 & 41.9 & 41.9 & 0.00 & 0.00 & 0.00 & 0.00 & 0.00 & 0.00 & 0.00 & 0.00 \\
\hline & 1 & 42.1 & 42.2 & 41.7 & 41.7 & 42.1 & 42.2 & 41.6 & 41.6 & 0.00 & 0.00 & 0.05 & 0.05 & 0.00 & 0.00 & 0.24 & 0.24 \\
\hline & 2 & 42.2 & 41.8 & 42.3 & 42.2 & 42.2 & 41.8 & 42.4 & 42.2 & 0.00 & 0.00 & 0.05 & 0.00 & 0.00 & 0.00 & 0.24 & 0.00 \\
\hline & 3 & 41.4 & 42.1 & 42.3 & 42.0 & 41.4 & 42.1 & 42.4 & 42.0 & 0.00 & 0.00 & 0.05 & 0.00 & 0.00 & 0.00 & 0.24 & 0.00 \\
\hline & 4 & 42.0 & 42.0 & 41.7 & 41.8 & 42.0 & 42.0 & 41.6 & 41.8 & 0.00 & 0.00 & 0.05 & 0.00 & 0.00 & 0.00 & 0.24 & 0.00 \\
\hline & 5 & 41.7 & 41.9 & 41.8 & 41.9 & 41.6 & 41.9 & 41.8 & 41.9 & 0.05 & 0.00 & 0.00 & 0.00 & 0.24 & 0.00 & 0.00 & 0.00 \\
\hline \multirow{6}{*}{27} & $\mathbf{0}$ & 40.9 & 41.2 & 41.6 & 41.6 & 41.0 & 41.2 & 41.6 & 41.6 & 0.05 & 0.00 & 0.00 & 0.00 & 0.24 & 0.00 & 0.00 & 0.00 \\
\hline & 1 & 41.3 & 42.1 & 42.0 & 42.0 & 41.4 & 42.1 & 42.0 & 42.0 & 0.05 & 0.00 & 0.00 & 0.00 & 0.24 & 0.00 & 0.00 & 0.00 \\
\hline & 2 & 41.8 & 42.3 & 42.1 & 42.1 & 41.8 & 42.4 & 42.1 & 42.1 & 0.00 & 0.05 & 0.00 & 0.00 & 0.00 & 0.24 & 0.00 & 0.00 \\
\hline & 3 & 42.2 & 40.9 & 42.2 & 41.1 & 42.2 & 41.0 & 42.2 & 41.1 & 0.00 & 0.05 & 0.00 & 0.00 & 0.00 & 0.24 & 0.00 & 0.00 \\
\hline & 4 & 42.0 & 42.2 & 41.5 & 41.8 & 42.0 & 42.2 & 41.6 & 41.8 & 0.00 & 0.00 & 0.05 & 0.00 & 0.00 & 0.00 & 0.24 & 0.00 \\
\hline & 5 & 42.1 & 41.8 & 41.8 & 41.8 & 42.1 & 41.8 & 41.8 & 41.8 & 0.00 & 0.00 & 0.00 & 0.00 & 0.00 & 0.00 & 0.00 & 0.00 \\
\hline \multirow{6}{*}{24} & 0 & 40.2 & 40.4 & 40.6 & 40.8 & 40.2 & 40.4 & 40.6 & 40.8 & 0.00 & 0.00 & 0.00 & 0.00 & 0.00 & 0.00 & 0.00 & 0.00 \\
\hline & 1 & 40.4 & 41.2 & 41.4 & 41.2 & 40.4 & 41.2 & 41.4 & 41.2 & 0.00 & 0.00 & 0.00 & 0.00 & 0.00 & 0.00 & 0.00 & 0.00 \\
\hline & 2 & 41.2 & 42.0 & 41.8 & 41.6 & 41.2 & 42.0 & 41.8 & 41.6 & 0.00 & 0.00 & 0.00 & 0.00 & 0.00 & 0.00 & 0.00 & 0.00 \\
\hline & 3 & 41.6 & 40.9 & 42.1 & 41.6 & 41.6 & 41.0 & 42.1 & 41.6 & 0.00 & 0.05 & 0.00 & 0.00 & 0.00 & 0.24 & 0.00 & 0.00 \\
\hline & 4 & 41.7 & 41.8 & 41.5 & 41.3 & 41.6 & 41.8 & 41.6 & 41.4 & 0.05 & 0.00 & 0.05 & 0.05 & 0.24 & 0.00 & 0.24 & 0.24 \\
\hline & 5 & 41.6 & 41.6 & 41.6 & 41.5 & 41.6 & 41.6 & 41.6 & 41.6 & 0.00 & 0.00 & 0.00 & 0.05 & 0.00 & 0.00 & 0.00 & 0.24 \\
\hline
\end{tabular}

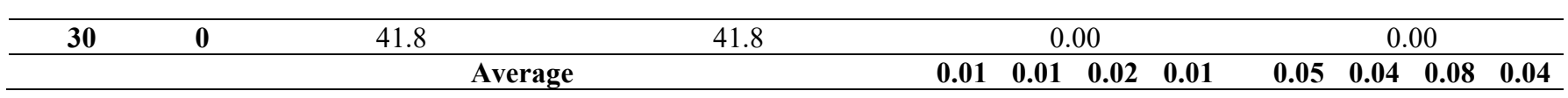

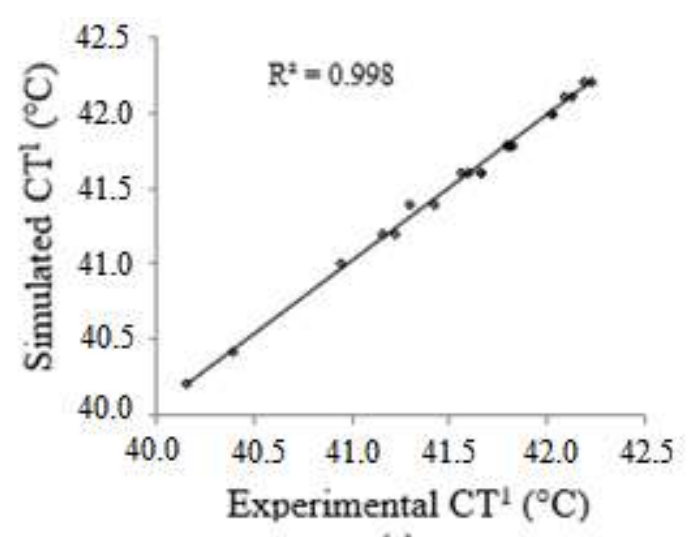

(a)

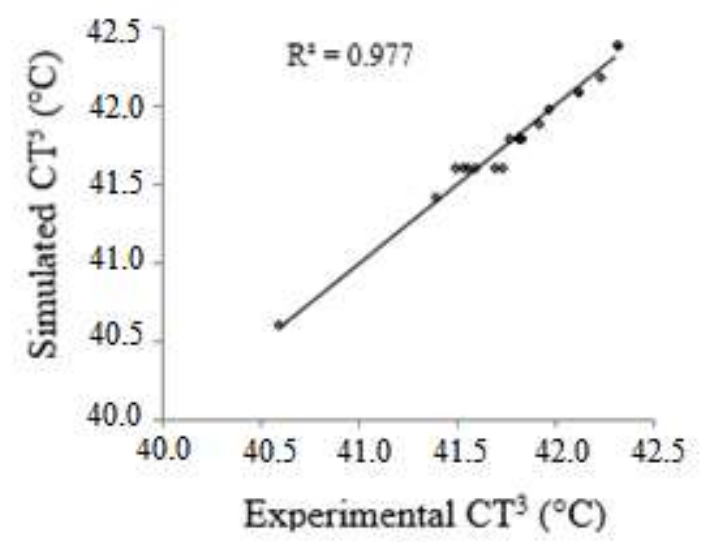

(c)

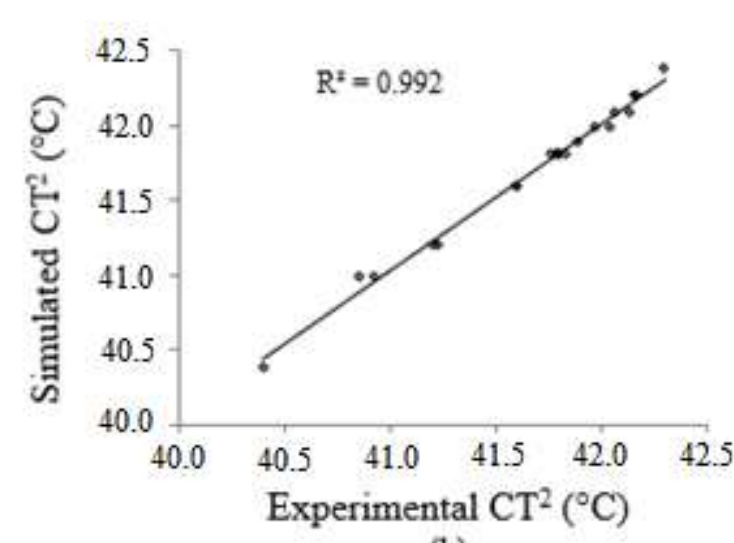

(b)

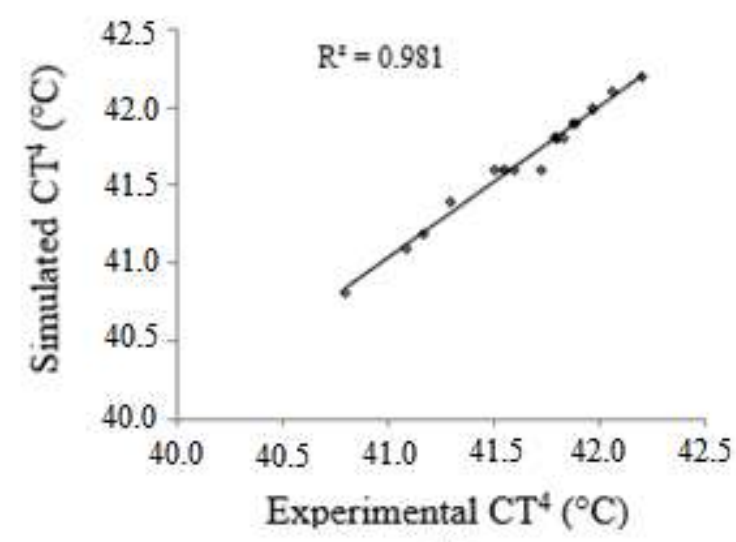

(d)

FIGURE 3. Linear regressions of cloacal temperatures obtained experimentally and simulated by the fuzzy model by varying the thermal stress duration: a) one day of thermal stress $\left(\mathrm{CT}^{1}\right)$, b) two days of thermal stress $\left(\mathrm{CT}^{2}\right)$, c) three days of thermal stress $\left(\mathrm{CT}^{3}\right)$, and d) four days of thermal stress $\left(\mathrm{CT}^{4}\right)$ in the second week of life. 
The response surface (Figure 4) illustrates the behavior of cloacal temperature as a function of the air dry-bulb temperature and thermal stress duration during the stress period. A depression in the temperature range from 29 to $24\left({ }^{\circ} \mathrm{C}\right)$ indicates the occurrence of a decrease in cloacal temperature, thus demonstrating that broiler chickens submitted to cold stress decrease their cloacal temperature, as well as the intensity of this reduction.

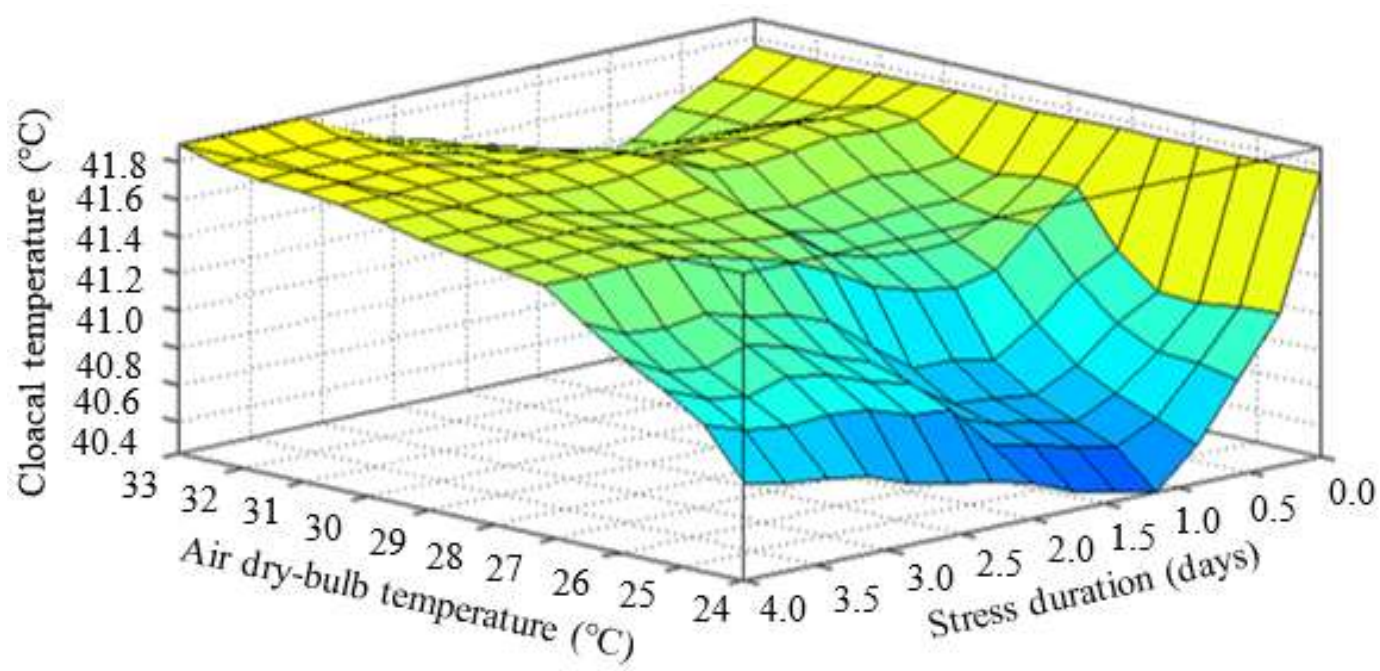

FIGURE 4. Cloacal temperature $\left({ }^{\circ} \mathrm{C}\right)$ simulated as a function of the air dry-bulb temperature $\left({ }^{\circ} \mathrm{C}\right)$ and thermal stress duration (days) for broiler chickens from one to 21 days of age.

In addition, the duration of 1 day can be considered as a reference in relation to the adaptation of birds to the thermal stress condition since the cloacal temperature of birds reduced to a minimum value when submitted to a certain temperature. From this period (1 day), the cloacal temperature increased, i.e. it presented a lower reduction in relation to the reference value under comfort conditions $\left(41.8^{\circ} \mathrm{C}\right)$. This behavior of cloacal temperature is because of their agglomerating behavior, in addition to possible physiological adjustments (Furtado et al., 2010).

\section{CONCLUSIONS}

The fuzzy model developed to predict the cloacal temperature of broiler chickens in the second week of life when submitted to different intensities and durations of thermal stress, was adequate to support the decisionmaking, providing values of standard deviations and percentage errors lower than 0.05 and $0.24 \%$, respectively.

Simulations carried out indicate that, from the second day of stress, the birds were able to adapt to the thermal conditions to which they were submitted.

\section{ACKNOWLEDGMENTS}

This study was financed in part by the Coordenação de Aperfeiçoamento de Pessoal de Nível Superior - Brasil (CAPES) - Finance code 001, Conselho Nacional de Desenvolvimento Científico e Tecnológico (CNPq) (Processo 307746/2014-3) and Fundação de Amparo à Pesquisa do Estado de Minas Gerais (FAPEMIG).

\section{REFERENCES}

Abreu PG, Baêta FC, Abreu VMN (2000) Desempenho produtivo e bioeconômico de frangos de corte criados em diferentes sistemas de aquecimento. Revista Brasileira de Zootecnia 29(1):159-167. Available in:

http://www.scielo.br/scielo.php?script=sci_arttext\&pid=S1 516-35982000000100022\&lng=en\&nrm=iso. Accessed:

Oct 14, 2016.

Abreu PG, Abreu VM, Coldebella A, Hassemer MJ, Tomazelli IL (2012) Medidas morfológicas em função do peso e da idade da ave, por meio de imagens. Revista Brasileira Engenharia Agrícola e Ambiental 16(7):795801. Available in:

http://www.scielo.br/scielo.php?script=sci_arttext\&pid=S1 415-43662012000700014\&lng=en\&nrm=iso. Accessed: Oct 14, 2016.

Campos AT, Castro JDO, Schiassi L, Yanagi Junior T, Pires MDFÁ, Mattioli CC (2013) Prediction of free-stall occupancy rate in dairycattle barns through fuzzy sets. Engenharia Agrícola 33(6):1079-1089. Available in: http://www.scielo.br/scielo.php?script=sci_arttext\&pid=S0 100-69162013000600001\&lng=en\&nrm=iso. Accessed: Oct 14, 2016.

Castro JDO, Veloso AV, Yanagi Junior T, Fassani EJ, Schiassi L, Campos AT (2012) Estimate of the weight of japanese quail eggs through fuzzy sets theory. Ciência e Agrotecnologia 36(1):108-116. Available in: http://www.scielo.br/scielo.php?script=sci_arttext\&pid=S1 413-70542012000100014\&lng=en\&nrm=iso. DOI: http://dx.doi.org/10.1590/S1413-70542012000100014 
Cherri AC, Alem Junior DJ, Silva IN (2011) Inferência fuzzy para o problema de corte de estoque com sobras aproveitáveis de material. Pesquisa Operacional 31(1):173-195. Available in: http://www.scielo.br/scielo.php?script=sci_arttext\&pid=S0 101-74382011000100011\&lng=en\&nrm=iso. DOI: http://dx.doi.org/10.1590/S0101-74382011000100011

Cobb-Vantress (2008) Broiler management guide. Cobb, $65 \mathrm{p}$.

Costa JHS, Saraiva EP, Santos LD (2012) Efeito do ambiente sobre indicadores fisiológicos na produção de frangos de corte. Revista Verde de Agroecologia e Desenvolvimento Sustentável 7(4):54-58. Available in: http://www.gvaa.com.br/revista/index.php/RVADS/article/ view/1395/pdf_620. Accessed: Sep 20, 2016.

Curtis SE (1983) Environmental management in animal agriculture. Ames, The Iowa State University, 410 p.

Ferreira L, Yanagi Junior T, Lacerda WS, Rabelo GF (2012) A fuzzy system for cloacal temperature prediction of broiler chickens. Ciência Rural 42(1):166-171. Available in: $\mathrm{http}: / /$ www.scielo.br/scielo.php?script=sci_arttext\&pid=S01 03-84782012000100027\&lng=en\&nrm=iso. DOI: http://dx.doi.org/10.1590/S0103-84782012000100027

Furlan RL (2006) Influência da temperatura na produção de frangos de corte. In: Simpósio Brasil Sul de Avicultura. Chapecó, SBA. Anais...

Furtado DA, Rocha HP, Nascimento JWB, Silva JHV (2010) Índíces de conforto térmico e concentração de gases em galpões avícolas no semiárido Paraibano. Engenharia Agrícola 30(6):993-1002. Available in: http://www.scielo.br/pdf/eagri/v30n6/a01v30n6.pdf. Accessed: Oct 14, 2015.

Ganga GMD, Carpinetti LCR, Politano PR (2011) A fuzzy logic approach to supply chain performance management. Gestão \& Produção 18(4):755-774. Available in: http://www.scielo.br/pdf/gp/v18n4/a06v18n4.pdf. DOI: http://dx.doi.org/10.1590/S0104-530X2011000400006

Marchini CFP, Silva PL, Nascimento MRBM, Beletti ME, Guimarães EC, Soares HL (2009) Intestinal morphometry of the duodenal mucosa in broiler chickens underwent to high cyclic environment temperature. Arquivo Brasileiro de Medicina Veterinária e Zootecnia 61(2):491-497. Available in:

http://www.scielo.br/scielo.php?script=sci_arttext\&pid=S0 102-09352009000200029\&lng=en\&nrm=iso. DOI: http://dx.doi.org/10.1590/S0102-09352009000200029

Medeiros CM, Baêta FDC, Oliveira RD, Tinôco IDFF, Albino LFT, Cecon PR (2005) Efeitos da temperatura, umidade relativa e velocidade do ar em frangos de corte. Engenharia na Agricultura 13(4):277-286. Available in: https://bioclimatologia.files.wordpress.com/2012/11/efeitosda-temperatura-aves-de-corte.pdf. Accessed: Oct 14, 2016.
Nazareno AC, Pandorfi H, Almeida GLP, Giongo PR, Pedrosa EMR, Guiselini C (2009) Avaliação do conforto térmico e desempenho de frangos de corte sob regime de criação diferenciado. Revista Brasileira de Engenharia Agrícola e Ambiental 13(6). Available in: http://www.scielo.br/scielo.php?script=sci_arttext\&pid=S1 415-43662009000600020\&lng=en\&nrm=iso. Accessed: Oct 14, 2016.

Pandorfi H, Almeida GLP, Guiselini C (2012) Zootecnia de precisão: princípios básicos e atualidades na suinocultura. Revista Brasileira de Saúde e Produção Animal 13(2):558-568. Available in: http://www.scielo.br/pdf/rbspa/v13n2/a23v13n2.pdf. Accessed: Oct 6, 2016.

Ponciano PF, Yanagi Junior T, Schiassi L, Campos AT, Nascimento JD (2012) Sistema fuzzy para predição do desempenho produtivo de frangos de corte de 1 a 21 dias de idade. Engenharia Agrícola 32(3):446-458. Available in: http://www.scielo.br/scielo.php?script=sci_arttext\&pid=S01 00-69162012000300004\&lng=en\&nrm=iso. Accessed: Oct 14, 2016.

Rostagno HS, Albino LFT, Donzele JL, Gomes PC, Oliveira RF, Lopes DC, Ferreira AS, Barreto SLT, Euclides RF (2011) Tabelas brasileiras para aves e suínos: composição de alimentos e exigências nutricionais. Viçosa, UFV, 3ed. 252 p.

Silva MAN, Hellmeister Filho P, Rosário MF, Coelho AAD, Savino VJM, Garcia AAF, Silva IJO, Menten JFM (2003) Influência do sistema de criação sobre o desempenho, condição fisiológica e o comportamento de linhagens de frango de corte. Revista Brasileira de Zootecnia 32(1):208-213. Available in:

http://www.scielo.br/scielo.php?script=sci_arttext\&pid=S1 516-35982003000100026\&lng=en\&nrm=iso. Accessed:

Oct 14, 2016.

Silva SCM, Costa WS (2004) Aquisição de conhecimento: o grande desafio na concepção de sistemas especialistas. Sinergia 5(2):135-141. Available in:

http://www2.ifrn.edu.br/ojs/index.php/HOLOS/article/vie wFile/71/77. Accessed: Oct 14, 2015.

Silva IJO, Vieira FMC (2010) Ambiência animal e as perdas produtivas no manejo pré-abate: o caso da avicultura de corte brasileira. Archivos de Zootecnia 59(1):113-31. Available in: http://www.uco.es/organiza/servicios/publica/az/php/img/ web/08_11_34_1869REVISIONAmbienciaSilva.pdf. Accessed: Sep 22, 2016. 
Schiassi L, Melo NSM, Tavares GF, Souza ÍP, Araújo HB, Della Giustina C (2013) Modelagem Fuzzy Em Parâmetros De Bem-Estar Humano. Nativa 1(1):8-12. Available in: http://periodicoscientificos.ufmt.br/index.php/nativa/article/ view/1329/pdf. Accessed: Oct 14, 2016.

Schiassi L, Yanagi Junior T, Reis GM, Abreu LHP, Campos AT, Castro JO (2015) Modelagem Fuzzy aplicada na avaliação do desempenho de frangos de corte. Revista Brasileira de Engenharia Agrícola e Ambiental 19(2):140146. Available in: http://www.scielo.br/pdf/rbeaa/v19n2/1415-4366-rbeaa19-02-0140.pdf. DOI: http://dx.doi.org/10.1590/18071929/agriambi.v19n2p140-146
Tao X, Xin H (2003) Acute synergistic effects of air temperature, humidity, and velocity on homeostasis of market-size broilers. Transactions of the ASAE 46(2):491497. Available in: http://lib.dr.iastate.edu/cgi/viewcontent.cgi?article=1144\& context=abe_eng_pubs. Accessed: Oct 14, 2015.

Yanagi Júnior T, Schiassi L, Abreu LHP, Barbosa JA, Campos AT (2012) Procedimento fuzzy aplicado à avaliação da insalubridade em atividades agrícolas. Engenharia Agrícola 32(3):432-434. Available in: http://www.scielo.br/scielo.php?script=sci_arttext\&pid=S0 100-69162012000300002\&lng=en\&nrm=iso. Accessed: Oct 14, 2016. 